\title{
OLIGODENDROGLIOMA IN A PATIENT WITH AIDS: CASE REPORT AND REVIEW OF THE LITERATURE
}

\begin{abstract}
SUMMARY
In the last years, new techniques of neuroimages and histopathological methods have been added to the management of cerebral mass lesions in patients with AIDS. Stereotactic biopsy is necessary when after 14 days of empirical treatment for Toxoplasma gondii encephalitis there is no clinical or neuroradiologic improvement. We report a woman with AIDS who developed a single focal brain lesion on the right frontal lobe. She presented a long history of headache and seizures. After two weeks of empirical treatment for toxoplasma encephalitis without response, a magnetic resonance image with spectroscopy was performed and showed a tumoral pattern with a choline peak, diminished of $\mathrm{N}$-acetyl-aspartate and presence of lactate. A stereotactic biopsy was performed. Histopathological diagnosis was a diffuse oligodendroglioma type A. A microsurgical resection of the tumor was carried out and antiretroviral treatment was started. To date she is in good clinical condition, with undetectable plasma viral load and CD4 T cell count $>200$ cell/uL.
\end{abstract}

KEYWORDS: Focal brain mass; Oligodendroglioma; Acquired immunodeficiency syndrome; AIDS.

\section{INTRODUCTION}

Primary central nervous system lymphoma (PCNSL) is the most frequent neoplasm diagnosis to be considered in patients infected with the human immunodeficiency virus type-1 (HIV-1) and focal brain lesions. However, malignant gliomas or other cerebral tumors may often occur in patients with the acquired immunodeficiency syndrome (AIDS) and have been reported in these patients in several series ${ }^{11}$. We report a case of oligodendroglioma in an AIDS patient and review of the literature.

\section{CASE REPORT}

A 31-year old woman presented a generalized seizure and was referred to our Unit of Infectious Diseases. She had a history of intravenous drug addiction and a diagnosis of AIDS in 1988. She had experienced intermittent headaches and some seizure episodes for 18 months without diagnosis. On physical examination she was alert and had no neurological deficit or papilledema. Serology for toxoplasmosis was IgM negative and IgG 1/64. The CD4 T cell count was 42 cells/uL. A brain magnetic resonance imaging (MRI) was performed and demonstrated a solitary intracerebral mass lesion with hypointense signal in T1 and hypertense signal in T2 weighted images, involving the right frontal lobe and the insula with moderate peripheral edema and without enhancement after gadolinium administration. A presumptive clinical and radiological diagnosis of toxoplasma encephalitis (TE) was made and empirical antitoxoplasma treatment (pirimetamine, sulfadiazine and leucovorine) was initiated. After 2 weeks of empirical treatment, she developed a new seizure episode and headache, and a MRI spectroscopy was performed. The lesion failed to show any change and spectroscopy demonstrated a choline peak with diminished $\mathrm{N}$-acetyl aspartate (NAA) and presence of lactic acid. Spectroscopic and radiological findings and his history of HIV/AIDS disease suggested a primary central nervous system lymphoma (PCNSL) and a stereotactic brain biopsy was performed. The patient's recovery following the biopsy procedure was uneventful. Histopathological examination of the specimen disclosed a monomorphous glioma of moderate cellularity with uniform round nuclei and clear cytoplasm. Small gemistocytes were also observed. Tumor cells showed a trend to infiltrate the non-tumoral brain. Histopathologic diagnosis was diffuse oligodendroglioma type A (Fig. 1, 2).

Antiretroviral therapy was started and four months after diagnosis, a microsurgical resection of the tumor through a pterional craniotomy was carried out. The patient had an uneventful postoperative course, and three days after surgery she was discharged.

To date, she remains on highly active antiretroviral therapy (HAART) based on zidovudine plus lamivudine plus efavirenz with a good clinical, immunological and virological response. Twenty eight months after the onset of neurological symptoms, is still in good clinical condition and without neurological deficit. The CD4 T cell count is $>200$ cell/uL and the plasma viral load was undetectable. 


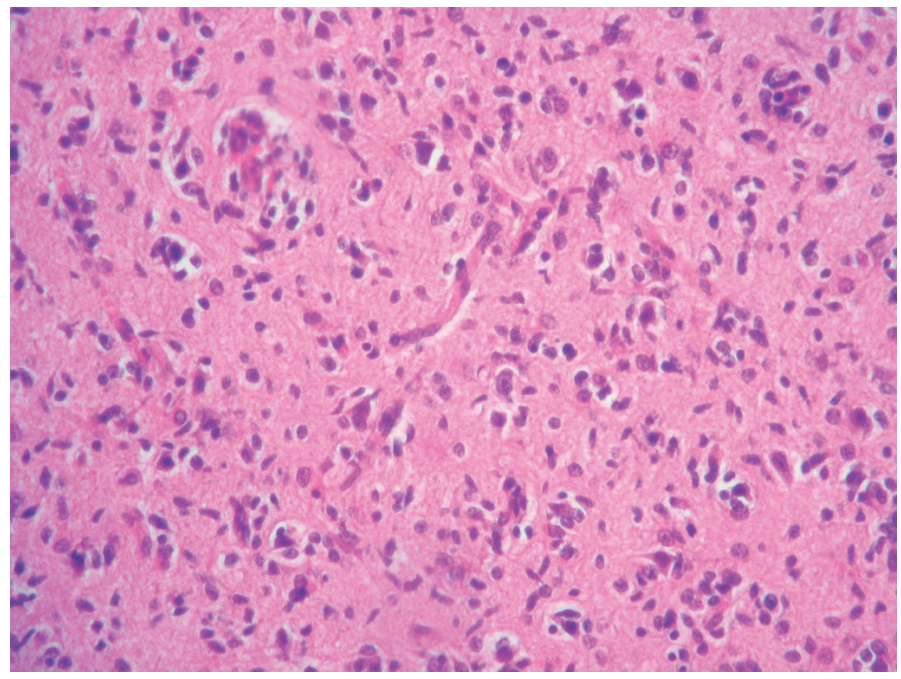

Fig. 1 - Photomicrograph, haematoxylin-eosin stain x 400, demonstrates moderate cellularity, and a perivascular infiltrate with atypical neoplastic oligodendrocytes with uniform round nucleus and perinuclear halo.

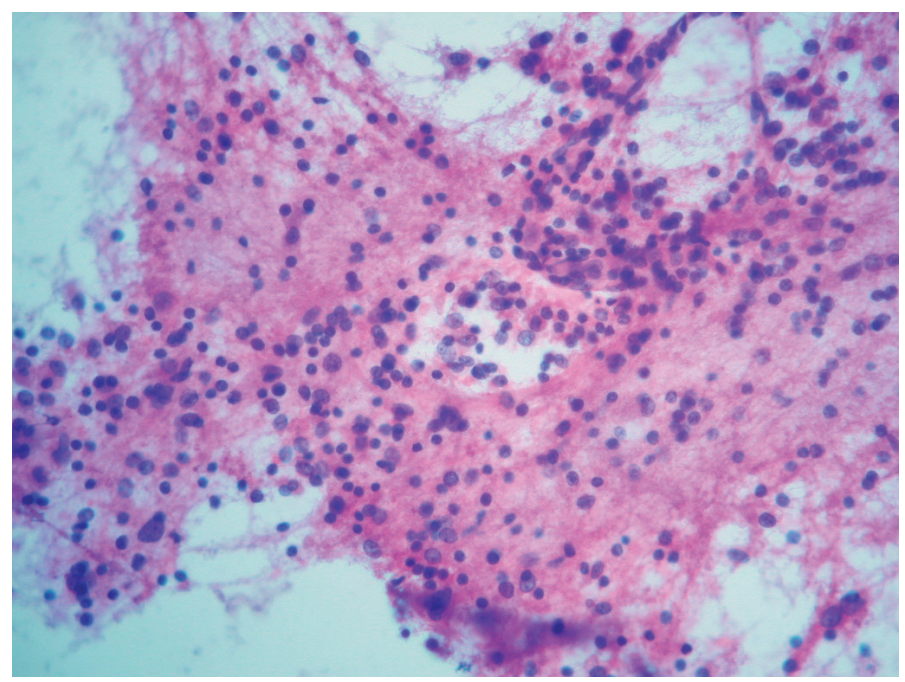

Fig. 2 - Photomicrograph, haematoxylin-floxin stain x 250, showed neoplastic oligodendrocytes and small gemistocytes.

\section{DISCUSSION}

Neurological involvement in patients with AIDS is common. Approximately $40 \%$ to $60 \%$ of patients with AIDS develop some neurological disorder at some stage of the disease. Glioma comprise a collection of tumors arising from their glial precursors within the central nervous system (CNS). The malignant glioma is the most common primary brain neoplasm, but it is not generally included in the differential diagnosis of enhancing lesions of the CNS in patients with the acquired immunodeficiency syndrome. Three histological types of diffuse infiltrative tumors are recognized by the World Health Organization (WHO) classification of gliomas: astrocytomas, oligodendrogliomas and oligoastrocytomas ${ }^{10}$. These tumors are further classified by subtypes and by histological grading as either low grade (WHO grade II) or anaplastic
(WHO grade III). Grade of tumor appears to be the most significant prognosticator ${ }^{1}$.

The diagnosis of oligodendrogliomas has been based in typical microscopic features ${ }^{5}$. Moreover, a characteristic gen alteration, allelic loss of chromosomes $1 \mathrm{p}$ and $19 \mathrm{q}$, may help to identify an oligodendrogliomal component. The concurrent loss of chromosomal arms $1 p$ and $19 q$ appears to identify a subgroup with a more favorable prognosis and a greater response to postoperative treatment ${ }^{4}$. Histologically distinguishing between pure oligodendrogliomas from other gliomas is very important in determining if chemotherapy may be an effective treatment ${ }^{2}$. Resorting to morphological criteria and other common features, the prevalence of the oligodendroglioma has been estimated to range from $5 \%$ to $7 \%$ of all glial tumors 5 . However, several recent studies of these tumors have focused on the significance of quantitatively assessing tumor proliferation using bromodeoxyuridine, MIB-1/Ki-67 and proliferating cell nuclear antigen ${ }^{7,8}$. In this context, and using expanded criteria, it is not unlikely that the oligodendrogliomas (or mixed tumor) are underdiagnosed, so that it has been suggested that the oligodendrogliomas may represent $25 \%$ to $33 \%$ of all glial tumors ${ }^{8,9}$.

Although PCNSL and TE continue to be the most common intracranial lesions in HIV-infected patients, other pathologic entities should be included in the differential diagnosis of enhancing lesions of the CNS in patients with AIDS.

However, the low incidence of this association reported in the medical literature could be a sign of the nonexistence of a pathogenesis relation between AIDS and the development of gliomas.

Up to 1999 , only 28 HIV-infected patients with primary brain tumors other than PCNSL have been reported in the literature. In 14 patients of this series, tumor was diagnosed a median of 2 years after the diagnosis of HIV. In our patient, the time interval between HIV diagnosis and tumor diagnosis was 18 months.

In 1999, BLUMENTHAL et al. ${ }^{3}$ published another report on eight patients; four of them had a diagnosis of AIDS as our patient and five were glioblastoma multiforme, the most aggressive and the most common of all gliomas ${ }^{12}$. The median of CD4 T cell count of Blumenthal's series was $169 \mathrm{cell} / \mathrm{uL}^{3}$; our patient had less than $50 \mathrm{CD} 4 \mathrm{~T}$ cell/uL at the time of neoplasm diagnosis. However, there was no relation between higher or lower grade tumor histology based on CD4 count; neither was there any association between CD4 count and tumor outcome ${ }^{3}$.

The most common location of these tumors is in the frontal lobes (40\% to $70 \%$ ), in the white matter and with little or no surrounding edema. Our patient had a right frontal lesion, without contrast enhancement and presenting perilesional edema of the white matter. Less frequently, the oligodendroglioma may involve other parts of the brain, the brainstem, cerebellum, third ventricle and the spinal cord. The oligodendroglioma grows slowly and the interval between the onset of symptoms and the diagnosis is protracted; in this specific case, the interval was 18 months.

As in our patient, the first symptom in over half of the patients is a focal or generalized seizure and $70 \%$ of patients with oligodendroglioma develop seizures during the evolution of the disease. Only one third 
exhibit focal cerebral signs and about half of all cases have increased intracranial pressure by the time surgery is performed. Gliomas may be included in the differential diagnosis of cerebral mass lesions in AIDS patients. Early stereotactic biopsy is needed to establish the diagnosis and is recommended by many authors ${ }^{6}$. A correct diagnosis has a significant impact on patient survival and a poor outcome is related with a delay in establishing the correct diagnosis ${ }^{13}$. Surgical excision is the treatment of choice for these tumors; however, a number of patients have recurrences within a few months after surgery. We conclude that a routine histopathological diagnosis of focal mass lesions in patients with AIDS and a poor response after 2 weeks of empirical antitoxoplasma treatment might disclose gliomas to be more common than currently recognized $^{14}$.

\section{RESUMEN}

\section{Oligodendroglioma en un paciente con sida: reporte de caso y revisión de la literatura}

En los últimos años, las nuevas técnicas de neuroimágenes y diversos métodos de diagnóstico histopatológico se han agregado al manejo clínico de las lesiones de masa cerebral ocupante en los pacientes con sida. La biopsia estereotáxica es necesaria cuando, luego de dos semanas de tratamiento empírico para toxoplasmosis cerebral, no se comprueba mejoría clínica ni neurorradiológica. Presentamos una paciente con sida que desarrolló una lesión cerebral a nivel del lóbulo frontal derecho. Como antecedente refirió una larga historia de cefalea y convulsiones. La resonancia nuclear magnética con espectroscopia de voxel único ubicado a nivel de la lesión mostró un patrón de lesión tumoral con pico de colina, déficit de $\mathrm{N}$-acetil-aspartato y presencia de ácido láctico. La biopsia estereotáxica y el estudio histopatológico permitieron arribar al diagnóstico de oligodendroglioma difuso de tipo A. Se le efectuó resección por microcirugía y tratamiento antirretroviral de alta eficacia. Actualmente la paciente se encuentra en buen estado clínico, con carga viral indetectable y recuento de linfocitos T CD4 + > de 200 cél/uL.

\section{REFERENCES}

1. ALLAM, A.; RADWI, A.; EL WESHI, A. \& MASSOUNAH, L.M. - Oligodendroglioma: an analysis of prognostic factors and treatment results. Amer. J. clin. Oncol., 23: 170-175, 2000.
2. BEHIN, A.; HOANG-XUAN, K.; CARPENTIER, A.F. \& DELATTRE, J.Y. - Primary brain tumors in adults. Lancet, 361: 323-331, 2003.

3. BLUMENTHAL, D.T.; RAIZER, J.J.; ROSENBLUM, M.K. et al. - Primary intracranial neoplasms in patients with HIV. Neurology, 52: 1648-1651, 1999.

4. BURGER, P.C. - What is an oligodendroglioma? Brain Path., 12: 257-259, 2002.

5. BURGER, P.C.; RAWLINGS, C.E.; COX, E.B. et al. - Clinicopathologic correlations in the oligodendroglioma. Cancer, 59: 1345-1352, 1987.

6. CHAMBERLAIN, M.C. - Gliomas in patients with acquired immunodeficiency syndrome. Cancer, 74: 1912-1914, 1994.

7. COONS, S.W. \& JOHNSON, P.C. - Regional heterogeneity in the proliferative activity of human gliomas as measured by the Ki-67 labeling index. J. Neuropath. exp. Neurol., 52: 609-618, 1993.

8. COONS, S.W.; JOHNSON, P.C.; SCHEITHAUER, B.W.; YATES, A.J. \& PEARL, D.K. - Improving diagnostic accuracy and interobserver concordance in the classification and grading of primary gliomas. Cancer, 79: 1381-1393, 1997.

9. DAUMAS-DUPORT, C.; VARLET, P.; TUCKER, M.L. et al. - Oligodendrogliomas Part 1. Patterns of growth, histological diagnosis, clinical and imaging correlations: a study of 153 cases. J. Neurooncol., 34: 37-59, 1997.

10. FORTIN, D.; CAIRNCROSS, G.J. \& HAMMOND, R.R. - Oligodendroglioma: an appraisal of recent data pertaining to diagnosis and treatment. Neurosurgery, 45: 1279-1291, 1999.

11. GILDENBERG, P.L. - Acquired immunodeficiency syndrome and central nervous system tumors. J. Neurosurg., 93: 156-157, 2000.

12. HOLLAND, E.C. - Glioblastoma multiforme: the terminator. Proc. nat. Acad. Sci. (Wash.), 97: 6242-6244, 2000.

13. SADLER, M.; BRINK, N.S. \& GAZZARD, B.G. - Management of intracerebral lesions in patients with HIV: a retrospective study with discussion of diagnostic problems. Quart. J. Med., 91: 205-217, 1998.

14. VANNEMREDDY, P.S.; FOWLER, M.; POLIN, R.S.; TODD, J.R. \& NANDA, A. Glioblastoma multiforme in a case of acquired immunodeficiency syndrome: investigation on a possible oncogenic influence of human immunodeficiency virus on glial cells. Case report and review of the literature. J. Neurosurg., 92: 161-164, 2000.

Received: 15 January 2004

Accepted: 16 June 2004 